\title{
Publisher Correction: Prediction of organic homolytic bond dissociation enthalpies at near chemical accuracy with sub-second computational cost
}

Peter C. St. John (1D, Yanfei Guan (1), Yeonjoon Kim (1), Seonah Kim (1) \& Robert S. Paton (D)

Correction to: Nature Communications https://doi.org/10.1038/s41467-020-16201-z, published online 11 May 2020.

The original version of this Article contained some errors in Fig. 7, in which there were four structures where one of the atoms was inadvertently displaced to the right of the structures. 
The correct version of Fig. 7 is

a

\section{Site of oxidative degradation}

Experiment:

Weak $\mathrm{C}-\mathrm{H}$ o 1st weakest

Bonds (DFT) Others<smiles>COn1cnc2c1c(=O)n([13CH3])c(=O)n2C</smiles>

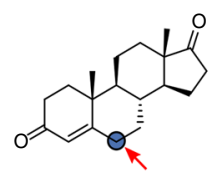<smiles>CCOc1cc(OC)ccc1OC</smiles><smiles>COC(=O)Oc1ccccc1C(=O)O</smiles><smiles></smiles>

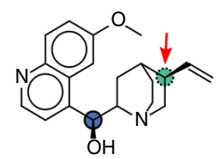

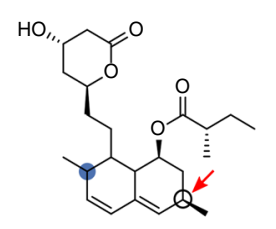<smiles>C=C(C)C1C=CC(CC(C)(C)C)CC1</smiles><smiles>CC(C)(C)C1CCC(OC2=C(O)C(=O)c3ccccc3C2=O)CC1</smiles><smiles>CCCCCc1cc(O)c2c(c1)OC1(C)OC[C@@H]2CCC1(C)C</smiles>

Weak $\mathrm{C}-\mathrm{H}$ - 1st weakest Bonds (ML) 2 2nd (within $3 r d$ $3 \mathrm{kcal} \mathrm{mol}^{-1}$ ) $\quad 5$ th<smiles>CC(=O)Nc1ccc(O[Ge](C)(C)C)cc1</smiles>

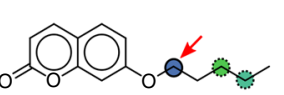<smiles>COc1ccc2c(c1)C13CCC(CC1(C)O3)N2C</smiles><smiles></smiles><smiles></smiles><smiles>COc1cccc(Nc2ccccc2C(=O)O)c1[O-]</smiles><smiles>Cc1cccc2c1OCC(CC(C)N)O2</smiles><smiles>CC1CN(C(=N)N)Cc2ccccc21</smiles><smiles>COOC(N)=O</smiles><smiles></smiles><smiles>CCOc1ccc2c(c1)OCCC1C2CCC2(C)C(O)CCC12</smiles><smiles>CCC(=O)C1(C)CCC2C3COC4=CC(=O)CCC4(C)C3CCC21C</smiles>

b
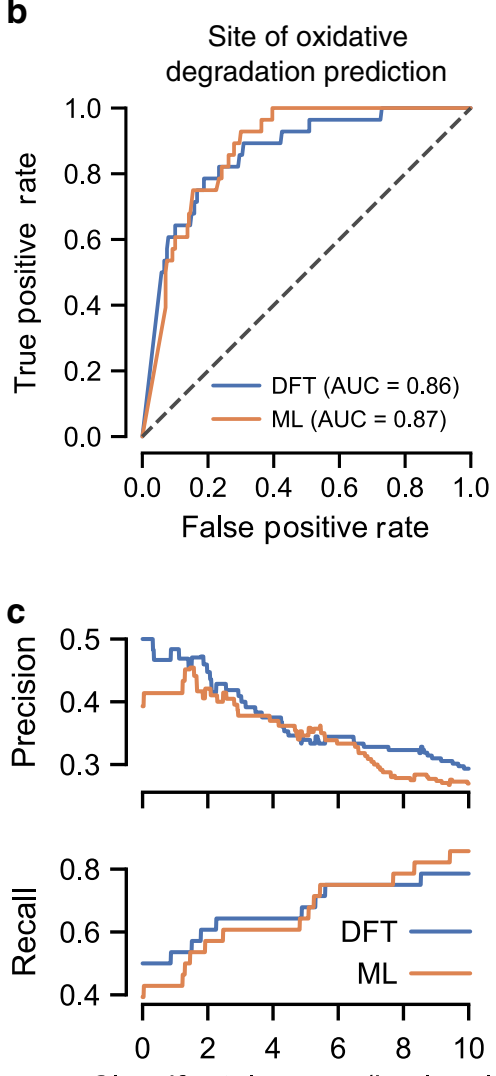

Classifer tolerance (kcal mol ${ }^{-1}$ )

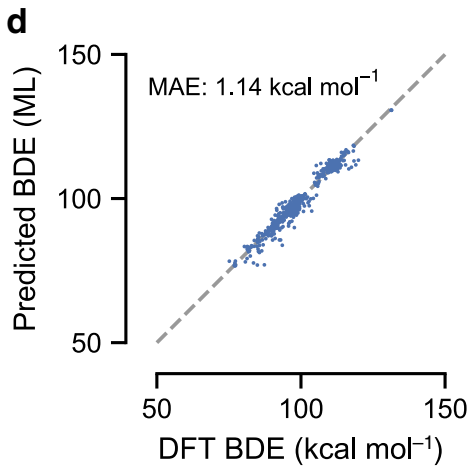


which replaces the previous incorrect version from the original pdf of the paper.

a

\section{Site of oxidative degradation Experiment: $\pi$}

Weak C-H O 1st weakest Bonds (DFT) others<smiles>COn1c(=O)n2c(=O)n(OC)n2c1=O</smiles><smiles>CCOc1ccccc1N(C(N)=O)c1ccccc1OC</smiles>

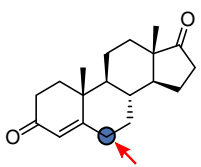<smiles>COc1ccc(OC)c(OC)c1</smiles><smiles>COC(=O)Oc1ccccc1C(=O)O</smiles>

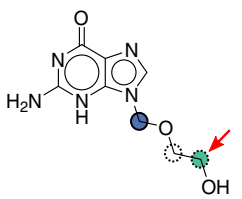<smiles>CC=C(C)ONC(=O)Nc1c(C)cccc1OC</smiles>

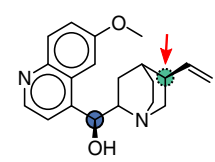

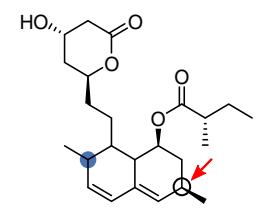<smiles>C=C(C)C1CCC(CC)OC1</smiles><smiles>CC(C)(C)C1CCC(O)C(O)C1=C1C(=O)c2ccccc2C(=O)C1O</smiles>

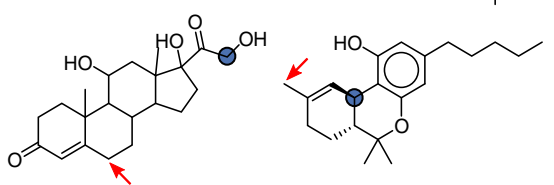

Weak $\mathrm{C}-\mathrm{H}$ - 1st weakest

Bonds (ML) 2nd

(within $3 \mathrm{rd}$

$3 \mathrm{kcal} \mathrm{mol}^{-1}$ ) $\quad 5$ th<smiles>CC(=O)Nc1ccc(O[Ge](C)(C)C)cc1</smiles><smiles>CCOc1cccc(Nc2ccccc2C(=O)O)c1C</smiles><smiles>C/C=C\COc1ccc2ccc(=O)oc2c1</smiles>

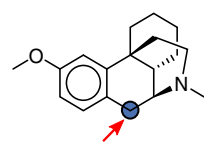<smiles>COC(=O)N(OC(C)C)c1cccc(-c2ccnc3c(C#N)cnn23)c1</smiles>

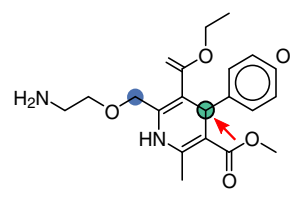<smiles>CCOc1cccc(Nc2ccccc2C(=O)O)c1O</smiles><smiles>Cc1cccc2c1OC1OCC21</smiles>

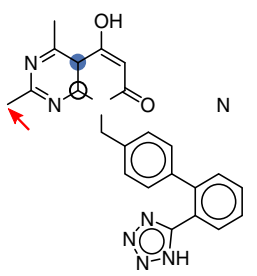<smiles>CCOC(N)=O</smiles><smiles>CCOc1ccc2c(c1)CCC1CCC3(C)C(O)CCC3CC21CO</smiles><smiles>CCC(=O)C1(C)CCC2C3COC4C=C(O)CCC4(C)C3CCC21C</smiles>

b
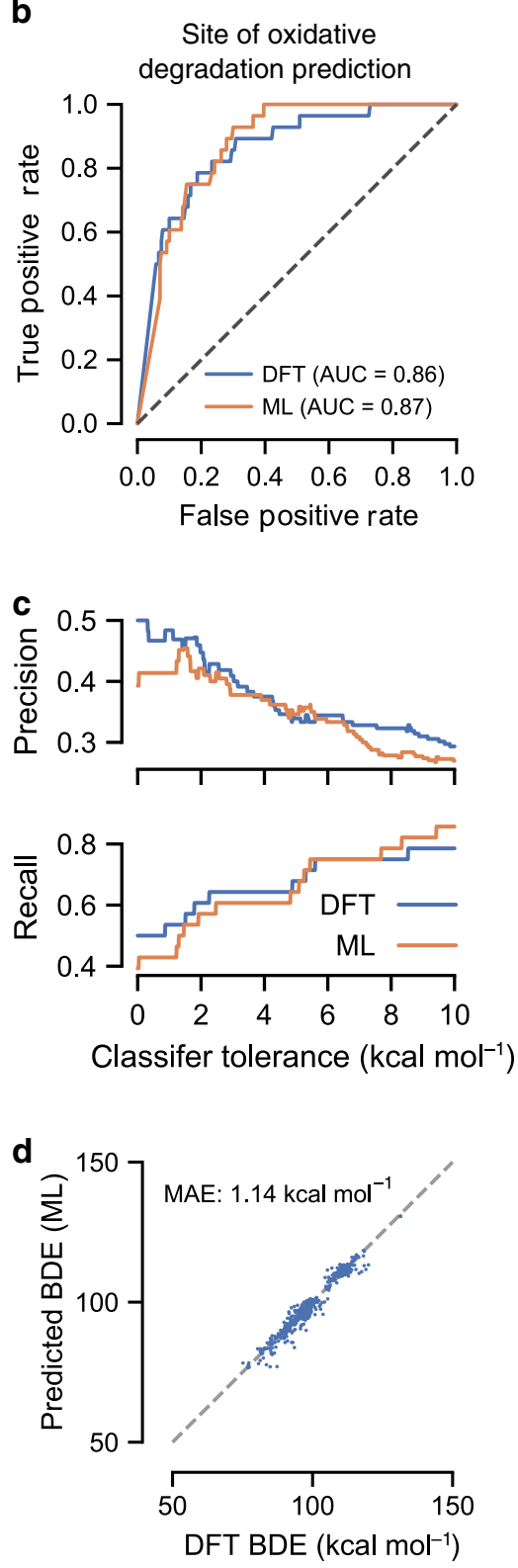

This has been corrected in the PDF and HTML versions of the Article.

Published online: 11 June 2020

\footnotetext{
(c) Open Access This article is licensed under a Creative Commons Attribution 4.0 International License, which permits use, sharing, adaptation, distribution and reproduction in any medium or format, as long as you give appropriate credit to the original author(s) and the source, provide a link to the Creative Commons license, and indicate if changes were made. The images or other third party material in this article are included in the article's Creative Commons license, unless indicated otherwise in a credit line to the material. If material is not included in the article's Creative Commons license and your intended use is not permitted by statutory regulation or exceeds the permitted use, you will need to obtain permission directly from the copyright holder. To view a copy of this license, visit http://creativecommons.org/licenses/by/4.0/.
}

(C) The Author(s) 2020 